\title{
Opinion and Special Articles: Cerebellar Ataxia and Liver Failure Complicating IPEX Syndrome
}

Joshua Rim, MD, Melissa Byler, CGC, Ariane Soldatos, MD, MPH, Luigi Notarangelo, MD, Emily Leibovitch, PhD, Steven Jacobson, PhD, Mark Gorman, MD, Robert Roger Lebel, MD, and Klaus Werner, MD, PhD

Neurology ${ }^{\circledR}$ 2021;96:e956-e959. doi:10.1212/WNL.0000000000011195

Immunodysregulation, polyendocrinopathy, and enteropathy, X-linked (IPEX) syndrome is an autoimmune condition caused by mutations in the Forkhead Box P3 (FOXP3) gene, which maps to chromosome Xp11.23 (OMIM \#304790). ${ }^{1}$ It typically presents within the first year of life with watery diarrhea, eczematous dermatitis, and endocrinopathy (most commonly diabetes mellitus). ${ }^{1}$ Most children have other autoimmune phenomena including Coombspositive anemia, thrombocytopenia, neutropenia, and tubular nephropathy. ${ }^{1}$ Bone marrow transplantation is the only definitive cure for IPEX syndrome. ${ }^{2}$ Neurologic involvement in IPEX syndrome has not been well characterized in the literature, based on a current Ovid MEDLINE search. Without aggressive immunosuppression or bone marrow transplantation, the majority of affected boys die within the first 1 to 2 years of life from metabolic derangements or sepsis. ${ }^{1}$ Diagnosis is based on clinical features and whole exome sequencing that reveals a pathogenic FOXP3 variant. $^{1}$

FOXP3, on Xp11.23, comprises 12 exons, encoding a 431-amino acid protein, FOXP3, a member of the Forkhead (FKH) family of transcription factors (OMIM \#300292). ${ }^{1}$ At least 70 pathogenic variants of FOXP3 are known, with a wide spectrum of clinical phenotypes associated even in the same variant. $^{2}$

FOXP3 acts upon the immune system by modulating and suppressing interleukin-2, suppressing effector cytokines, and antagonizing Th17 differentiation. ${ }^{2}$ In effect, the FOXP3 protein plays a critical role in the maturation and function of regulatory $\mathrm{T}$ cells $\left(\mathrm{T}_{\mathrm{reg}}\right)$, which are required for effective maintenance of tolerance and prevention of autoimmune diseases, throughout the body. ${ }^{2}$

\section{Case Description}

A 19-year-old man at the age of 2 years presented with jaundice and liver failure due to autoimmune hepatitis, for which he received a liver transplant. He had recurrent episodes of rejection of varying severity but was ultimately stable on prednisone $5 \mathrm{mg}$ daily, mycophenolate mofetil $750 \mathrm{mg}$ twice daily, and tacrolimus $2.5 \mathrm{mg}$ twice daily. At age 12 he developed progressive difficulties with handwriting, with bilateral hand tremors beginning by age 14 . $\mathrm{He}$ developed insulin-dependent diabetes mellitus at age 14 as well. His tremors progressed to the arms and then to the legs by the age of 15 , at which time he presented to clinic for further evaluation. He denied any family history of neurologic disease.

The differential diagnosis for a progressive subacute-chronic cerebellar ataxia includes structural lesions, infection, toxic-metabolic derangements, genetic etiologies, and autoimmune etiologies.

Neuroimaging was performed upon presentation to rule out a structural lesion, followed by serum testing for toxic-metabolic causes. Serial brain MRI at ages 15 and 16 revealed stable cerebellar atrophy with ex vacuo dilation of the fourth ventricle. No other lesions were observed (figure, A). Serum vitamin E level was $6.1 \mu \mathrm{g} / \mathrm{mL}$ (normal 4.6-17.8).

\author{
Correspondence \\ Dr. Rim \\ joshua.k.rim@gmail.com
}

\footnotetext{
From the Cleveland Clinic Foundation (J.R.), Neurological Institute, OH; SUNY Upstate Medical University Genetics Section (M.B., R.R.L.), Syracuse, NY; National Institute of Neurological Disorders and Stroke (NINDS) (A.S., E.L., S.J.), Bethesda; National Institute of Allergy and Infectious Diseases (NIAID) (L.N.), Bethesda, MD; Boston Children's Hospital (M.G.), Pediatric MS and Related Disorders and Neuro-immunology, MA; and Duke University (K.W.), Department of Pediatrics, Durham, NC.

Go to Neurology.org/N for full disclosures. Funding information and disclosures deemed relevant by the authors, if any, are provided at the end of the article.
} 

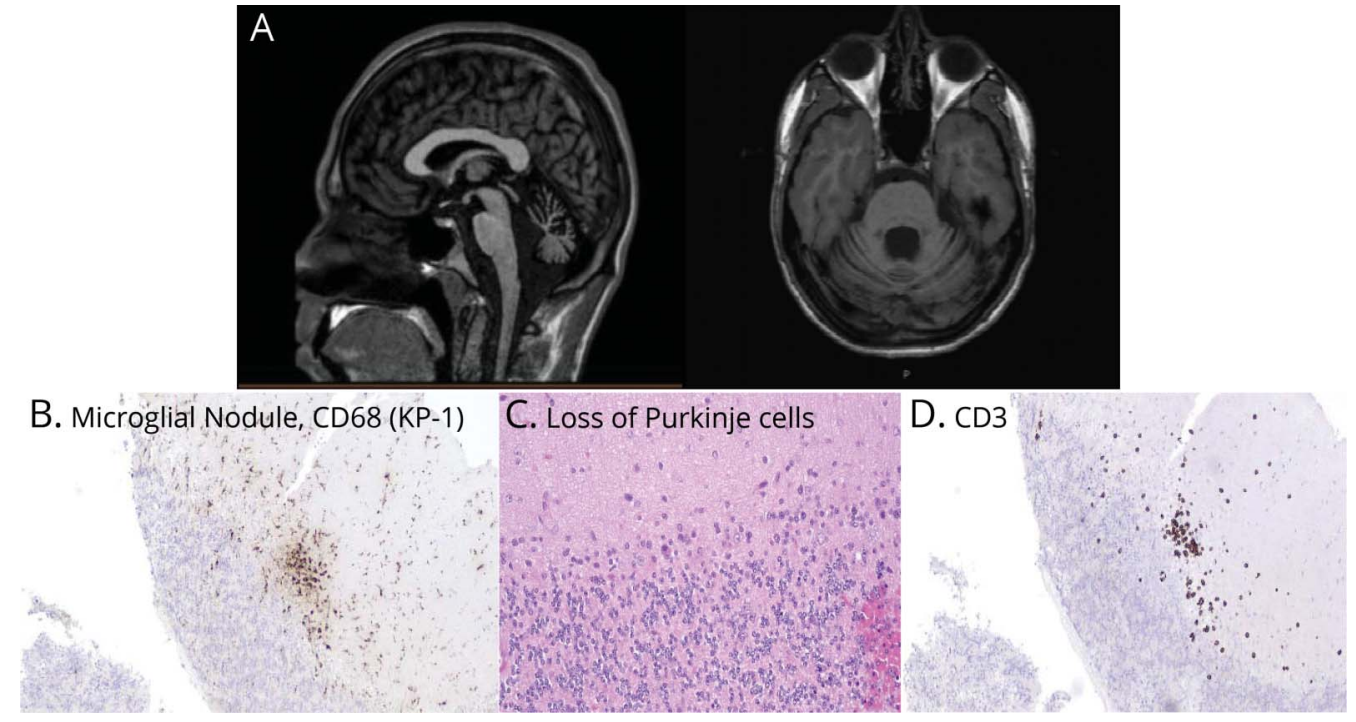

(A) Sagittal and axial MRI brain, from Soldatos et al. ${ }^{10}$ (B-D) Cerebellar biopsies with immunostaining, from Soldatos et al. ${ }^{10}$

As the patient showed progressive ataxia from an early age, we considered genetic causes and whole exome sequencing was sent. Whole exome sequencing is a next-generation sequencing method that targets only the exons or translated portion of a patient's genome. It is thought to be an effective method for identifying disease-causing mutations. ${ }^{3}$ Whole exome sequencing at age 16 revealed a FOXP3 mutation (IVS2+1G>C), consistent with IPEX syndrome.

In addition, a panel testing for mutations and triple repeat expansions of 42 genes associated with hereditary cerebellar ataxia was sent. This panel included those repeat expansion mutations that would have been missed by whole exome sequencing. These genes included ADCK3, SCA28 (AFG3L2), ANO10, Aprataxin (APTX), ATM, DRPLA (ATN1), SCA1 (ATXN1), SCA10 (ATXN10), SCA2 (ATXN2), SCA3/MJD (ATXN3), SCA7 (ATXN7), SCA8 (ATXN8OS), SCA8 (CACNA1A), CACNA1A, CACNB4, EEF2, FGF14, FLVCR1, Friedreich Ataxia (FXN), GRM1, ITPR1, KCNA1, SCA13 (KCNC3), KCND3, MRE11A, MTPAP, PDYN, POLG, SCA12 (PPP2R2B), SCA14 (PRKCG), SACS, SETX, SIL1 (MSS), SLC1A3, SCA5 (SPTBN2), SYNE1, SYT14, SCA17, TDP1, TGM6, TTBK2, TTPA (AVED), and VAMP1. No known pathogenic variants were identified.

The liver failure and insulin-dependent diabetes were wellexplained by IPEX syndrome. However, the etiology of the progressive cerebellar atrophy was not yet clear.

The symptoms continued to progress, and by age 17 the patient required assistance to walk. By age 18, he developed scanning speech, bilateral end-gaze nystagmus, bilateral intention tremor $(<5 \mathrm{~Hz})$ with ataxic finger to nose testing and heel to shin testing, and a wide-based ataxic gait.
The patient was referred to the NIH for further testing and underwent lumbar puncture and cerebellar biopsy. Routine CSF analysis with flow cytometry and viral PCR were performed at NIH, and serum and CSF autoantibody testing were sent to Mayo Clinic. CSF analysis showed elevated protein (50 $\mathrm{mg} / \mathrm{dL}$ ) and immunoglobulin G index (0.69) (normal $\leq 0.62$ ) as well as paired systemic and CSF oligoclonal bands. Viral PCRs of whole blood and CSF were unremarkable, except for high titers of human herpesvirus 6 (HHV6) (HHV6B PCR serum $>2,500,000$ copies/mL). One copy of HHV6 viral DNA was found in each of the patient's cells and in the patient's mother, suggesting inherited chromosomally integrated HHV6B. Serum autoantibody results were nonspecific and revealed low titers of N-type calcium channel Ab (0.09 nmol/ $L)$ without $P / Q$ type antibodies. Serum and CSF were negative for cell surface neuronal antigen antibodies (NMDA-R, VGKC, GAD65, GABA-B, AMPA-R, ANNA-1/2/3, AGNA-1, PCA-2, PCATr, amphiphysin, CRMP-5, P/Q Ca channel, muscle AChR, AChR ganglionic neuronal, NMO/AQP4 FACS).

Cerebellar biopsy showed loss of Purkinje cells, a CD3 T-cell infiltrate, and CD68 (KP-1) microglial nodules (figure, B-D).

\section{Discussion}

Our patient met clinical and whole exome criteria for IPEX syndrome and experienced progressive cerebellar ataxia. The search for acquired causes of his cerebellar atrophy was unrevealing.

The patient's medications, particularly tacrolimus and mycophenolate, are associated with mild to severe neurologic toxicities ranging from uncomplicated headache to posterior 
reversible encephalopathy syndrome, but are not known to be associated with global cerebellar atrophy. ${ }^{4}$

Serum and CSF assays for metabolic or infectious causes were unrevealing. Serum vitamin E was normal. Our patient displayed high titers of HHV6B in the blood and CSF. While HHV6 infection is associated with infectious and postinfectious acute cerebellar ataxia, it is not associated with a chronically progressive course as seen in this patient. ${ }^{5}$

Other infectious causes of progressive cerebellar degeneration involve progressive multifocal leukoencephalopathy (PML), Whipple disease, and prion disease. There was no evidence of PML on neuroimaging, and such a slowly progressive course would not be expected in prion disease. The patient has not exhibited altered mentation or the pathognomonic oculofacial-skeletal myorhythmia of CNS Whipple disease. ${ }^{6}$

We also considered autoimmune causes separate from IPEX syndrome. The autoimmune diseases of the cerebellum generally include paraneoplastic syndromes (associated with Anti-Yo, Hu, Tr, CV2, Ri, Ma2, and VGCC), gluten ataxia, and anti-Gad65 antibody ataxia. A paraneoplastic process would be unlikely in a male patient of teenage years, and gluten ataxia and anti-GAD65 antibody ataxia usually present in older female patients with other autoimmune diseases (T1DM, thyroiditis, hemolytic anemia). ${ }^{7}$ These autoantibodies were not found in CSF analysis.

Other inherited disorders, such as X-linked disorders with cerebellar dysgenesis, are known, and many have been wellcharacterized. $^{8}$ The cardinal feature of these disorders is a cerebellar defect visible on neuroimaging, caused by gene mutations or genomic imbalances on the X-chromosome. ${ }^{8}$ Some of the disorders are characterized by specific neurologic presentations, but most involve significant developmental delay or intellectual disability, which our patient did not manifest. ${ }^{8}$

In addition, specific mutations on the $\mathrm{X}$ chromosome have been characterized in each case, and our whole exome sequencing did not coincide with any known pathogenic variants known to be associated with cerebellar dysgenesis. ${ }^{8}$

The cerebellar biopsy was similarly unrevealing, showing a pattern of inflammation and cell death that is T cell-mediated, yet nonspecific (figure, B-D).

Our patient's cerebellar degeneration may have been a result of his liver failure early in life. ${ }^{9}$ However, it is unusual that his cerebellar degeneration appeared and progressed years following liver transplant. It is therefore most likely that our patient is the first reported to have manifested CNS involvement in IPEX syndrome in the form of progressive autoimmune degeneration.

The patient's brother, age 9, has been found to harbor the same X-linked FOXP3 mutation, which is known to be carried by their mother. He has manifested features of inflammatory bowel disease and dermatitis, but no neurologic problems. Bone marrow transplantation is pending for both brothers.

Patients with IPEX syndrome and neurologic decline should have a thorough neurologic examination looking for possible cerebellar degeneration.

\section{Acknowledgment}

This research was supported in part by the Intramural Research Program of the NIH, National Institute of Allergy and Infectious Diseases, and National Institute of Neurological Disorders and Stroke.

\section{Study Funding}

No targeted funding reported.

\section{Disclosure}

Dr. Rim, M. Byler, Dr. Soldatos, Dr. Notarangelo, Dr. Leibovitch, Dr. Jacobson, Dr. Gorman, and Dr. Lebel report no disclosures relevant to the manuscript. Dr. Werner is on the Novartis speaker bureau. Go to Neurology.org/N for full disclosures.

Appendix Authors

\begin{tabular}{|c|c|c|}
\hline Name & Location & Contribution \\
\hline $\begin{array}{l}\text { Joshua Rim, } \\
\text { MD }\end{array}$ & Cleveland Clinic, $\mathrm{OH}$ & $\begin{array}{l}\text { Drafted and edited manuscript, } \\
\text { liaison between different clinical } \\
\text { teams }\end{array}$ \\
\hline $\begin{array}{l}\text { Melissa Byler, } \\
\text { CGC }\end{array}$ & $\begin{array}{l}\text { SUNY Upstate } \\
\text { Medical University, } \\
\text { Syracuse, NY }\end{array}$ & $\begin{array}{l}\text { Patient's genetics counselor, } \\
\text { major role in acquiring data, } \\
\text { liaison with patient }\end{array}$ \\
\hline $\begin{array}{l}\text { Ariane } \\
\text { Soldatos, MD, } \\
\text { MPH }\end{array}$ & $\begin{array}{l}\text { NINDS, Bethesda, } \\
\text { MD }\end{array}$ & $\begin{array}{l}\text { Major role in acquiring data, } \\
\text { interpreting data, edited } \\
\text { manuscript }\end{array}$ \\
\hline $\begin{array}{l}\text { Luigi } \\
\text { Notarangelo, } \\
\text { MD }\end{array}$ & NIAID, Bethesda, MD & $\begin{array}{l}\text { Major role in acquiring data, } \\
\text { interpreting data, edited } \\
\text { manuscript }\end{array}$ \\
\hline $\begin{array}{l}\text { Emily } \\
\text { Leibovitch, } \\
\text { PhD }\end{array}$ & $\begin{array}{l}\text { NINDS, Bethesda, } \\
\text { MD }\end{array}$ & $\begin{array}{l}\text { HHV6 research testing, revised } \\
\text { intellectual content }\end{array}$ \\
\hline $\begin{array}{l}\text { Steven } \\
\text { Jacobson, } \\
\text { PhD }\end{array}$ & $\begin{array}{l}\text { NINDS, Bethesda, } \\
\text { MD }\end{array}$ & $\begin{array}{l}\text { HHV6 research testing, revised } \\
\text { intellectual content }\end{array}$ \\
\hline $\begin{array}{l}\text { Mark } \\
\text { Gorman, MD }\end{array}$ & $\begin{array}{l}\text { Boston Children's } \\
\text { Hospital, MA }\end{array}$ & $\begin{array}{l}\text { Edited manuscript, referring } \\
\text { neuroimmunologist }\end{array}$ \\
\hline $\begin{array}{l}\text { Robert Roger } \\
\text { Lebel, MD }\end{array}$ & $\begin{array}{l}\text { SUNY Upstate } \\
\text { Medical University, } \\
\text { Syracuse, NY }\end{array}$ & $\begin{array}{l}\text { Patient's first geneticist, edited } \\
\text { manuscript, revised intellectual } \\
\text { content }\end{array}$ \\
\hline $\begin{array}{l}\text { Klaus } \\
\text { Werner, MD, } \\
\text { PhD }\end{array}$ & $\begin{array}{l}\text { Duke University, } \\
\text { Durham, NC }\end{array}$ & $\begin{array}{l}\text { Patient's first neurologist, edited } \\
\text { manuscript, revised intellectual } \\
\text { content }\end{array}$ \\
\hline
\end{tabular}

\section{References}

1. Kniffin C.Immunodysregulation, Polyendocrinopathy, and Enteropathy, X-linked; IPEX. OMIM: IPEX. 1992. Available at: omim.org/entry/304790? search=ipex syndrome\&highlight=ipex syndromic syndrome [updated 2014 Nov 6]. Accessed June 5, 2018. 
2. Bacchetta R, Barzaghi F, Roncarolo MG. From IPEX syndrome to FOXP3 mutation: a lesson on immune dysregulation. Ann NY Acad Sci 2018;1417:5-22.

3. Rabbani B, Tekin M, Mahdieh N. The promise of whole-exome sequencing in medical genetics. J Hum Genet 2014;59:5-15.

4. Dhar R. Neurologic complications of transplantation. Neurocrit Care 2018;28:4-11.

5. Hata A, Fujita M, Morishima T, Kumakura A, Hata D. Acute cerebellar ataxia associated with primary human herpesvirus- 6 infection: a report of two cases. J Paediatr Child Health 2008;44:607-609.

6. Louis ED, Lynch T, Kaufmann P, Fahn S, Odel J. Diagnostic guidelines in central nervous system Whipple's disease. Ann Neurol 1996;40:561-568.
7. Mitoma $\mathrm{H}$, Manto M, Hampe CS. Immune-mediated cerebellar ataxias: from bench to bedside. Cerebellum Ataxias 2017;4:16.

8. Zanni G, Bertini ES. X-linked disorders with cerebellar dysgenesis. Orphanet J Rare Dis $2011 ; 6: 24$.

9. Balzano T, Forteza J, Molina P, et al. The cerebellum of patients with steatohepatitis shows lymphocyte infiltration, microglial activation and loss of Purkinje and granular neurons. Scientific Rep 2018;8:3004.

10. Soldatos A, DeRavin SS, Gorman M, et al. Cerebellar degeneration in a patient with IPEX syndrome. Poster presented at annual meeting of the Clinical Immunology Society; March 23-26, 2018; Seattle, Washington. 


\section{Neurology}

\section{Opinion and Special Articles: Cerebellar Ataxia and Liver Failure Complicating IPEX Syndrome \\ Joshua Rim, Melissa Byler, Ariane Soldatos, et al.}

Neurology 2021;96;e956-e959 Published Online before print November 9, 2020

DOI 10.1212/WNL.0000000000011195

This information is current as of November 9,2020

\section{Updated Information \&} Services

\section{References}

Subspecialty Collections

\section{Permissions \& Licensing}

Reprints including high resolution figures, can be found at: http://n.neurology.org/content/96/6/e956.full

This article cites 8 articles, 0 of which you can access for free at: http://n.neurology.org/content/96/6/e956.full\#ref-list-1

This article, along with others on similar topics, appears in the following collection(s):

\section{All Genetics}

http://n.neurology.org/cgi/collection/all_genetics

All Pediatric

http://n.neurology.org/cgi/collection/all_pediatric

Autoimmune diseases

http://n.neurology.org/cgi/collection/autoimmune_diseases

\section{Cerebellum}

http://n.neurology.org/cgi/collection/cerebellum

Tremor

http://n.neurology.org/cgi/collection/tremor

Information about reproducing this article in parts (figures,tables) or in its entirety can be found online at:

http://www.neurology.org/about/about_the_journal\#permissions

Information about ordering reprints can be found online:

http://n.neurology.org/subscribers/advertise

Neurology ${ }^{\circledR}$ is the official journal of the American Academy of Neurology. Published continuously since 1951, it is now a weekly with 48 issues per year. Copyright (C) 2020 American Academy of Neurology.. All rights reserved. Print ISSN: 0028-3878. Online ISSN: 1526-632X.

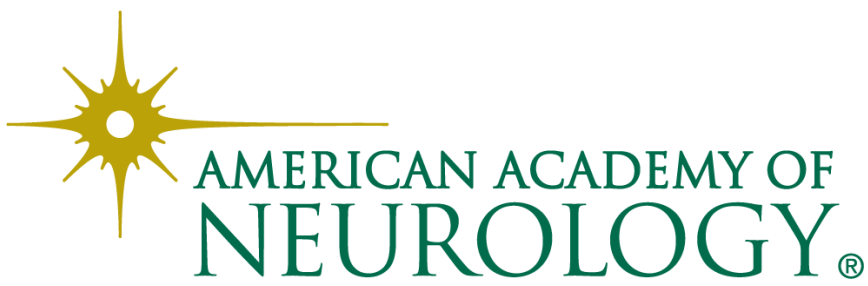

